\title{
Determinants of Internet Financial Disclosure in GCC Countries
}

\author{
Mohamed A. K. Basuony \\ Assistant Professor of Accounting, Department of Accounting \\ School of Business, American University in Cairo \\ AUC Avenue, P.O. Box 74, New Cairo, Postal Code: 11835, Cairo, Egypt \\ Tel: 20-2-2615-3259Ｅ-mail: Mohamed.basuony@aucegypt.edu
}

Ehab K. A. Mohamed

Professor of Accounting, Department of Accounting and Finance

Faculty of Management Technology, German University in Cairo

New Cairo, Postal Code: 11835, Cairo, Egypt

Tel: 20-2-2759-0764Ｅ-mail: ehab.kamel@guc.edu.eg

Received: February 8, 2014 Accepted: March 4, 2014 Published: June 1, 2014

doi:10.5296/ajfa.v6i1.5085 URL: http://dx.doi.org/10.5296/ajfa.v6i1.5085

\begin{abstract}
The purpose of this paper is to examine the determinants and characteristics of voluntary internet disclosures by listed companies in Saudi Arabia and Oman. This paper uses archival data from listed companies on Tadawul Stock Exchange and Muscat Securities Market. Binary Logistic Regression analysis is used to examine the determinants of internet financial reporting. Mann-Whitney test is used to examine the differences in disclosure characteristics between the two countries. The results of this study reveal that firm size is the major influencing factor that impacts internet financial reporting. The results reveal that a number of disclosure characteristics that differ significantly between the two countries. The paper provides insights into corporate internet disclosures in the GCC countries that will benefit all stakeholders with an interest in corporate reporting in this important region of the world.
\end{abstract}

Keywords: Internet, Financial reporting, Disclosure, Saudi Arabia, Oman, GCC 


\section{Introduction}

This paper investigates and reports on the extent, nature and determinants of internet financial reporting (IFR) by companies listed on the stock exchanges in Saudi Arabia and Oman. While IFR is fast becoming the norm in most western countries, there is little empirical evidence of the phenomenon in Gulf Cooperation Council (GCC) countries. Until recently, hard (paper) copies have been the primary means for communicating financial information to shareholders and other interested corporate stakeholders. Technological advances have made the internet a useful, timely and cost-effective tool for the communication of this information to stakeholders. The internet has the potential to revolutionize financial reporting. Companies can include the traditional annual reports together with additional financial and non-financial information in multiple formats (Jones and Xiao, 2004).

Questions persist as to whether corporate organizations in the GCC are availing themselves of the opportunity provided by the internet to communicate financial information to their stakeholders. While the use of the Internet for the communication of financial information raises a variety of challenging issues, there is little doubt about its benefits. This paper is an important first step in gauging the extent to which such benefits are being captured in the GCC. Given the increasing importance of IFR and the lack of empirical study on IFR practices in the Middle East, this paper provides an important contribution to filling the gap in our knowledge of this subject. This is of particular importance in a time when there is so much interest in investment opportunities in the GCC countries where rapid economic growth is fuelled by booming oil revenues.

Evidence of IFR practices in various countries have been presented by a number of academic and professional studies - see, for example, Craven and Marston (1999) and Gowthrope (2004) - UK, Deller et al. (1999) - US, UK and Germany, Gowthorpe and Amat (1999) Spain, Hedlin (1999) - Sweden, Lymer et al. (1999) - International Comparison, Pirchegger and Wagenhofer (1999) - Austria and Germany, Marston and Polei (2004) - Germany, Trites (1999) - US and Canada, Oyelere et al. (2003), Fisher et al. (2004) and Laswad et al. (2005) New Zealand, Marston (2003) - Japan, Xiao et al. (2004) - China, Smith and Peppard (2005) - Ireland, Khadaroo (2005) - Malaysia, and Chan and Wickramasinghe (2006) - Australia, Bozcuk et al. (2009) - Turkey, Ismail and Sobhy (2009) - Egypt, Mohamed et al. (2009) Oman, Salawu (2009) - Nigeria, Mohamed (2010) - Middle East. They indicate the growing use of the Internet for the corporate dissemination of information, including providing annual reports on the Internet, and that the extent and sophistication of IFR practices varies across countries. The objective of this paper is to study IFR practices in the GCC. The paper provides evidence of the extent and determinants of IFR in two GCC countries, namely Saudi Arabia and Oman. The understanding of IFR practices is important for standard setting purposes.

The objective of this paper is to examine internet financial reporting practices and determinants in companies listed in Tadawul Stock Exchange (Saudi Arabia) and Muscat Securities Market (Oman). The rest of this paper is structured as follows. A review of relevant literature is provided in the next section. The proposed research methodology is 
discussed in Section 3. Section four provides analyses and discussions on the extent, nature and determinants of IFR by companies listed in the two stock exchanges. Summary and conclusions are presented in the final section.

\section{Literature Review}

\subsection{Background}

The Internet provides a useful communication tool for corporate organizations. One of the main benefits of IFR is the potential for large savings in the cost of production and distribution of financial information. The Internet allows companies to reach a much wider range of stakeholders at a relatively lower cost. The use of IFR also leads to a reduction in incidental requests from non-shareholder financial statement users (Allam and Lymer, 2002; SEC, 2002, 2003a,b; Khadaroo, 2005) . The literature also documents a number of other benefits that may accrue from IFR (Baker and Wallage, 2000; Ettredge et al., 2001; Debreceny, et al., 2002; Wagenhofer, 2003; Jones and Xiao, 2004; Boritz and No, 2005). These include more equitable information dissemination among stakeholders as a result of the improved accessibility of the information. With IFR users can choose to access information that meets their specific needs as the Internet allows non-sequential access to information through the use of hyperlinks, interactivity and search facilities. IFR also presents companies with the opportunity to provide more information than is available in annual reports. The internet provides an opportunity for going beyond what is available in hard copy corporate financial statements to communicate additional financial information to users, possibly in real-time and on an interactive basis (McCafferty, 1995; Louwers et al., 1996; Green and Spaul, 1997; Trites and Sheehy, 1997; Trites, 1999; FASB, 2000; Ettredge et al., 2002; Wickramasinghe, 2006). IFR provides corporate organizations with a real opportunity to extend financial disclosure beyond the reproduction of a hard copy annual report and improve on the timeliness, scope, and interactivity of financial reporting, with multimedia, such as sound, animation and video, being used to potentially increase the understanding of information (Louwers et al., 1996; Ravlic, 2000; Wickramasinghe and Lichtenstein, 2006). These developments have a great potential impact on users (Wallman, 1997; Green and Spaul, 1997; Gowthrope and Flynn, 2001).

A number of IFR-related issues and challenges have been noted in the literature. It is possible that the dividing line between current financial information used by management and historical audited financial information made available to public users of financial information could be erased by online, real-time reporting (Green and Spaul, 1997; Hodge, 2001; Oyelere, 2003), with auditors being possibly required to provide opinion on such hitherto internal financial information (Trites and Sheehy, 1997; Lymer and Debreceny, 2003; Khadaroo, 2005). If IFR is installed as the only mode for communicating financial information it is likely that access to such information will be restricted to only those who possess costly computer equipment and skills. Hence, to ensure equitable access to financial information it will be necessary to ensure that the information being reported through corporate websites is also provided through other media of financial information disclosure (McCafferty, 1995). This could be seen as unnecessary duplication and may result in even 
greater costs in the Middle East where financial information is commonly disseminated in both English and Arabic.

Additional issues and challenges for IFR include possible errors in the extraction or re-keying process, which may affect the reliability and integrity of the financial information; Generally Accepted Accounting Practice (GAAP) implications of IFR; the use of the corporate websites for many diverse purposes, which may make the location of financial information difficult; and the acceptability of Internet financial reports as alternatives to hard copy annual reports among users of corporate financial information (Laswad et al., 2000).

By far the greatest challenge faced in the IFR environment is that of ensuring the security and integrity of the financial information published on corporate websites. Apart from possible errors in the publishing process, materials published on the web are susceptible to all manners of security risks. Financial information could, post-publication, be knowingly or unknowingly altered by parties both external and internal to the organization. There is a real risk that critical decisions could be made by users of financial information based on inaccurate financial information gleaned from corporate websites. The extent to which these issues are dealt with is likely to determine the long-term usefulness of the Internet as a medium of corporate financial information dissemination.

\subsection{Hypotheses Development}

Very little, if any, evidence exists on the extent and nature of IFR practices in the GCC countries. It is predicted that IFR is likely to overtake the hard-copy print form of financial information disclosure in the near future. It is therefore surprising that evidence on the variety of issues associated with this form of financial disclosure is currently not being publicly discussed. Such evidence will depend on the outcome of thorough, in-depth investigation and analysis, such as is being preliminarily undertaken in the current study. Therefore, considering the importance of IFR in disseminating financial information and the little research of these practices in emerging economies, the objective of this paper is to study the extent, practices and determinants of IFR in Saudi Arabia and Oman. While those countries share a number of characteristics due to being in the same region and sharing similar cultures, they are at different stages of development, or with different business environments that may affect the attributes of internet financial disclosure. This argument leads to the first hypothesis:

\section{$H_{1}$. There is a significant difference in the attributes of corporate internet disclosure between Saudi Arabia and Oman.}

Recent studies have provided evidence on the factors motivating the IFR behaviour of companies around the world. Given the voluntary nature of IFR, these studies sought to establish the reason why companies engage in IFR and the extent of such engagement. The majority of these studies have found corporate size to be a major factor, with IFR likely to provide greater economies of scale cost savings for larger firms (Ashbaugh et al., 1999; Craven and Marston, 1999; Pirchegger and Wagenhofer, 1999; Debreceny et al., 2002; 
Ettredge et al., 2002; Oyelere et al., 2003; Fisher et al., 2004; Chan and Wickramasinghe, 2006; Trabelsi, 2007). Evidence on other variables examined is largely inconclusive.

\section{Firm Size}

Several studies examine the relationship between firm size and voluntary disclosure (Malone et al., 1993; Ahmed and Nicholls, 1994; Raffournier, 1995; Haniffa and Cooke, 2002; Karim et al.,2006; Almilia and Surabaya 2009; Aly et al 2010). It is argued that stock market pressure forces large corporations to disclose more information on their websites to assist them in increasing their outside capital to enhance their performance. Hence, large corporations are more able to access financial markets through disclosing more information online (Bonso'n and Escobar, 2002). Large corporations can disclose information on the internet for lower costs as they have the resources to do so. Agency theory implies that large firms exhibit higher agency costs due to the information asymmetry between market participants (Jensen and Meckling, 1976). To reduce these agency costs, larger firms disclose a large flow of corporate information. While, according to the political cost hypothesis, large firms attract more financial analysts putting firms under higher pressure because they are more publicly visible (Boubaker et al., 2012). Due to the industrial competition between companies, smaller firms tend to hide their important information (Almilia and Surabaya 2009, Marston 2003). Moreover, large companies always have a larger number of products and their distribution networks are very complex than smaller firms. Thus, information disclosure is required more in large companies (Marston 2003; Aly et al 2010).

Empirical findings suggest a significant relationship between firm size and online disclosure (Hossain et al., 1995; Ashbaugh et al., 1999; Craven and Marston, 1999; Pirchegger and Wagenhofer, 1999; Brennan and Hourigan, 2000; Bonso'n and Escobar, 2002; Debreceny et al., 2002; Ettredge et al., 2002; Larra'n and Giner, 2002; Oyelere et al., 2003; Marston and Polei, 2004; Xiao et al., 2004; García-Borbolla et al., 2005; Bollen et al., 2006; Sriram and Laksmana, 2006; Ezat and El-Masry, 2008). This prompts the second research hypothesis:

\section{$H_{2 .}$ There is a positive relationship between firm size and IFR}

\section{Profitability}

It is suggested that firm profitability can be regarded as an indicator to good management, as management tends to disclose more information when the rate of return is high. Hence, profitable companies have extra financial resources to disseminate financial information voluntary and have more incentives to disclose to both the stakeholders and public that they are more profitable than their counterparts in the same industry. This can be justified by the agency theory, where managers of the highly profitable companies disseminate more information on their companies' website to achieve personal advantages such as the marinating their positions and justifying compensations (Singhvi and Desai, 1971; Wallace et al., 1994; Haniffa and Cooke, 2002). Furthermore, signaling theory suggests that profitable companies have an incentive to disclose more information, to signal the firm's profitability to investors and to raise capital at the lowest price (Oyeler et al., 2003; Marston and Polei, 2004). However, there are mixed results with some studies revealing significant relationship 
between firm profitability and internet financial disclosure (Ashbaugh et al., 1999; Ismail, 2002; Debreceny and Rahman, 2005), while other studies find no significant relationship between profitability and online financial disclosure (Larra'n and Giner, 2002; Oyelere et al., 2003; Marston and Polei, 2004; Xiao et al., 2004; Momany and Al-Shorman, 2006; Ezat and El-Masry, 2008). Thus, the third research hypothesis is:

\section{$H_{3}$. There is a positive relationship between profitability and IFR}

\section{Leverage}

Based on the agency theory, the agency costs of loan capital depend on the nature of claims held by outsiders. It suggests that the costs are higher for firms with proportionally more debt in the capital structure (Leftwich et al. 1981). Voluntary disclosure can reduce the agency costs by facilitating debt supplier's assessment of a firm's ability to meet its debts (Jensen and Meckling, 1976). Thus, it is suggested that firms that are highly leveraged are more inclined to try and satisfy debt suppliers by disseminating reliable information on the website to make these creditors more confident about the ability of the companies to pay their debts. Though this dissemination results in extra disclosure costs, providing reliable information to debt suppliers reduces agency costs. Likewise, shareholders demand more information to assess the firm's financial ability (Ismail, 2002; Larra'n and Giner, 2002; Oyelere et al., 2003; Xiao et al., 2004).

Nonetheless, the literature offers inconclusive evidence on the relationship between leverage and internet financial disclosure. Some studies show a significant positive relationship (Mitchell et al. 1995; Hossain et al. 1995; Xiao et al., 2004), other studies show a significant negative relationship (Meek et al., 1995), while others show an insignificant relationship (Brennanand Hourigan, 2000; Debreceny et al., 2002; Larra'n and Giner, 2002; Oyelere et al., 2003; Bollen et al., 2006; Ezat and El-Masry, 2008). Hence, the fourth hypothesis is:

\section{$H_{4}$ Firms that are highly leveraged are more inclined to practice IFR}

Industry Type

According to the signalling theory, companies within the same industry tend to adopt the same level of disclosure. When a company within an industry tends not to follow the same disclosure practices, including internet disclosures, as others in the same industry, then it may be interpreted as a signal that the company is hiding bad news (Craven and Marston, 1999). The difference in disclosure practices between different industries may be due to different industries having different proprietary costs of disclosure and some may be more technologically advanced than others (Ismail, 2002). Several studies examine the relationship between the type of business activity and internet financial disclosure. The findings are mixed with some studies revealing a significant relationship between internet financial disclosure and industry type (Ashbaugh et al., 1999; Craven and Marston, 1999; Brennan and Hourigan, 2000; Bonso'n and Escobar, 2002; García-Borbolla et al., 2005; Ismail, 2002; Oyelere et al., 2003, Ezat and El-Masry, 2008, Aly et al., 2010). However, others show insignificant relationship (Debreceny and Rahman, 2005; Larra'n and Giner, 2002; Trabelsi and Labelle, 2006). This leads us to the fifth research hypothesis: 


\section{$H_{5 .}$ There is a significant relationship between industry type and IFR}

\section{Audit Type}

It is suggested that audit quality is an important factor in improving firms' overall reporting practices. International audit firms are more likely to facilitate the diffusion of innovative practices, such as the internet financial reporting (Hail, 2002; Xiao et al., 2004). Agency theory suggests that auditing helps mitigate agency costs due to the interest conflicts between manager and shareholders. Big auditors are likely to be independent and could constrain managers to maintain more stringent disclosure standards (DeAngelo, 1981). Large international audit firms are likely to demand high-quality disclosure. This could be explained by the signalling theory because managers that hire large auditing firms signal to the market that they are willing to provide quality disclosures (Healy and Palepu, 2001).

The findings of some prior studies reveal a positive relationship between audit type and internet financial disclosure (Ahmed and Nicholls, 1994; Raffournier, 1995; Xiao et al., 2004; Boubaker et al., 2012). Though, other studies no significant relationship between audit type and disclosure (Wallace et al., 1994; Hossain et al., 1995; Abd El Salam, 1999, Aly et al., 2010). Therefore, the sixth research hypothesis is:

\section{$H_{6}$. Firms that are audited by a Big 4 audit firm are more inclined to practice IFR}

\section{Methodology}

The aim of this study is to investigate and document the extent and nature of IFR practices among firms listed on the GCC countries. The research methodology employed to accomplish this aim is presented in this section. The population of the study consists of firms that are publicly listed in the stock exchanges of KSA and Oman. Data is collected for 2011 as it is the most recent year for which company annual reports are available for the sample at the time of undertaking this research. Table (1) below shows the population and samples selected for each of stock exchanges:

Table 1. Population and samples per stock exchange

\begin{tabular}{|c|c|c|c|}
\hline & $\begin{array}{r}\text { KSA } \\
\text { (Tadawul) }\end{array}$ & $\begin{array}{r}\text { Oman } \\
(\mathrm{MSM})\end{array}$ & Total \\
\hline All listed companies & 156 & 126 & 282 \\
\hline Unavailable data & (3) & (13) & (16) \\
\hline Total & 153 & 113 & 266 \\
\hline
\end{tabular}

Finally, the sample of this study is 266 firms out of 282 after excluding 16 firms for those firms that have not available data. Moreover, theses 266 firms are consist of 153 firms from KSA, and 113 firms from Oman. Table 2 below shows the sample selected for each of stock exchange in each country. 


\section{Il Macrothink}

Table 2. Sample by Country

\begin{tabular}{lll} 
Country & Number of Companies & $\mathbf{\%}$ \\
\hline KSA & 153 & $57.5 \%$ \\
Oman & 113 & $42.5 \%$ \\
\hline Total & $\mathbf{2 6 6}$ & $\mathbf{1 0 0 . 0 \%}$ \\
\hline
\end{tabular}

Data regarding whether these companies have website or not were obtained via searching the names of these companies in internet search engines. Where corporate sites are available, we moved to the next stage of the data collection process by investigating the type of information provided at these sites. Four categories of information - company history/background, products/services, financial and other information - were of interest to us at this stage. The next stage of the data collection process involved querying the extent and nature of financial information provided on the corporate websites. Of interest are the type of financial information - that is, whether full financial statements and/or financial highlights; the format of presentation, that is whether PDF, HTML, other formats or a combination of these; and the volume of financial information presented. This data collection approach is similar to the one used in Craven and Marston (1999), Deller et al (1999), Oyelere et al (2003), and Laswad et al (2005).

The objective of this paper is to examine internet financial reporting practices and its determinants in firms listed in KSA stock exchange (Tadawul), and Oman stock market (MSM). Table (3) shows the definition and measurement of these variables.

Table 3. Definition and measurement of variables

\begin{tabular}{|c|c|c|}
\hline Symbol & Variable Definition & Measurement \\
\hline \multicolumn{3}{|c|}{ Dependent Variables } \\
\hline IFR & Internet Financial Reporting & If IFR exists $=1$; If it does not $=0$ \\
\hline \multicolumn{3}{|c|}{ Independent Variables (Determinants) } \\
\hline FrmSize & Firm Size & Natural log of total assets \\
\hline ROA & Return on Assets & Net Income / Total Assets \\
\hline Lvg & Leverage & Total Liabilities / Total Assets \\
\hline IndTyp & Industry Type & $\begin{array}{l}\text { Manufacturing }=1 \text {; Non-financial Services }=2 \text { 2; } \\
\text { Financial Services }=3\end{array}$ \\
\hline AudTyp & Auditor Type & If 'Big 4' = 1; otherwise $=0$ \\
\hline \multicolumn{3}{|c|}{ Control Variables } \\
\hline Market & Stock Market & Tadawul = $1 ;$ MSM = 2 \\
\hline
\end{tabular}




\section{Mll Macrothink}

\section{Results and Discussion}

\subsection{Descriptive Analysis}

Table 4 represents the descriptive statistics using minimum, maximum, mean and standard deviation for disclosure attributes (Panel A), while Panel B represents descriptive statistics for determinants of corporate internet disclosure as discussed in the literature review section.

Table 4 : Descriptive statistics

\begin{tabular}{lllll}
\hline & Min. & Max. & Mean & SD \\
\hline Panel A: & & & & \\
EWeb & 0 & 1 & 0.92 & 0.264 \\
AWeb & 0 & 1 & 0.63 & 0.483 \\
Investor Relation & 0 & 1 & 0.43 & 0.496 \\
Figures \& Graphs & 0 & 1 & 0.55 & 0.499 \\
Email Link & 0 & 1 & 0.92 & 0.264 \\
Multimedia & 0 & 1 & 0.82 & 0.388 \\
Format & 0 & 1 & 0.58 & 0.495 \\
CG Report & 0 & 1 & 0.20 & 0.397 \\
Company Information & 0 & 1 & 0.91 & 0.282 \\
Products \& Services Information & 0 & 1 & 0.91 & 0.287 \\
Forward Looking Information & 0 & 1 & 0.47 & 0.500 \\
General Financial Information & 0 & 1 & 0.62 & 0.485 \\
IFR & 0 & 1 & 0.58 & 0.495 \\
Current Annual Report & 0 & 1 & 0.52 & 0.500 \\
IFRYrs & 0 & 3 & 1.45 & 1.326 \\
& & & & \\
Panel B: & & & & \\
ROA & -0.68 & 0.86 & 0.004 & 0.122 \\
Audit Type & 0 & 1 & 0.80 & 0.397 \\
Industry Type & 1 & 3 & 1.82 & 0.806 \\
Lvg & 0.00 & 1.38 & 0.475 & 0.265 \\
FrmSize & 14.98 & 26.53 & 20.52 & 2.058 \\
\hline
\end{tabular}

The 266 companies listed on the two stock exchanges in KSA, and Oman has three industrial sectors. A distribution of the 266 companies among the different industrial sectors is presented in Table 5. 
Table 5. Sample Distribution

\begin{tabular}{llllll}
\hline Country & Manufacturing & $\begin{array}{l}\text { Non-Financial } \\
\text { Services }\end{array}$ & $\begin{array}{l}\text { Financial } \\
\text { Services }\end{array}$ & Total & \% \\
\hline KSA & 61 & 50 & 42 & 153 & $57.5 \%$ \\
Oman & 54 & 35 & 24 & 113 & $42.5 \%$ \\
\hline Total & $\mathbf{1 1 5}$ & $\mathbf{8 5}$ & $\mathbf{6 6}$ & $\mathbf{2 6 6}$ & \\
\hline \% & $\mathbf{4 3 . 2 \%}$ & $\mathbf{3 2 \%}$ & $\mathbf{2 4 . 8 \%}$ & & $\mathbf{1 0 0 . 0 \%}$ \\
\hline
\end{tabular}

Table 6 shows that the majority of companies (80.5\%) operating in the GCC hire Big 4 audit firms. The highest percentage is in KSA where about $84 \%$ of companies hire Big 4 audit firms and 76\% in Oman.

Table 6. Auditor Type

\begin{tabular}{llll}
\hline Country & Big $\mathbf{4}$ & Non-Big $\mathbf{4}$ & Total \\
\hline KSA & 128 & 25 & 153 \\
Oman & 86 & 27 & 113 \\
\hline Total & $\mathbf{2 1 4}$ & $\mathbf{5 2}$ & $\mathbf{2 6 6}$ \\
\hline $\boldsymbol{\%}$ & $\mathbf{8 0 . 5 \%}$ & $\mathbf{1 9 . 5 \%}$ & \\
\hline
\end{tabular}

A classification of "websiters" and "non-websiters" by country is provided in Table 7 and 8. Overall, 246 companies (92.5\%) have English websites, while only 168 companies (63.2\%) have Arabic websites. 150 companies (98\%) in KSA have English website and 144 companies (94\%) have Arabic website. 85\% of Oman listed companies have English websites and 21\% have Arabic websites. Generally, the proportion of website ownership appears good when compared with developed western countries such as the US, the UK, Australia and New Zealand (Lymer et al., 1999; Oyelere et al., 2003; Chan and Wickramasinghe, 2006).

Table 7. Listed Companies With or Without English Websites by Country

\begin{tabular}{llllll}
\hline Country & With Website & \multicolumn{2}{l}{ Without Website } & Total \\
\hline KSA & 150 & $98 \%$ & 3 & $2 \%$ & 153 \\
Oman & 96 & $85 \%$ & 17 & $15 \%$ & 113 \\
\hline Total & $\mathbf{2 4 6}$ & $\mathbf{9 2 . 5 \%}$ & $\mathbf{2 0}$ & $\mathbf{7 . 5 \%}$ & $\mathbf{2 6 6}$ \\
\hline
\end{tabular}

Table 8. Listed Companies With or Without Arabic Websites by Country

\begin{tabular}{llllll}
\hline Country & \multicolumn{2}{l}{ With Website } & \multicolumn{2}{l}{ Without Website } & Total \\
\hline KSA & 144 & $94 \%$ & 9 & $6 \%$ & 153 \\
Oman & 24 & $21 \%$ & 89 & $79 \%$ & 113 \\
\hline Total & $\mathbf{1 6 8}$ & $\mathbf{6 3 . 2 \%}$ & $\mathbf{9 8}$ & $\mathbf{3 6 . 8} \%$ & $\mathbf{2 6 6}$ \\
\hline
\end{tabular}




\section{Macrothink Institute ${ }^{\mathrm{TM}}$}

Table 9 provides description of internet disclosure attributes. Overall, all companies provide information on company, Email link and product and services with (100\%). On the other hand, only $21 \%$ of companies disclose corporate governance information and $46 \%$ have a section for investor relations. While $88 \%$ of companies use multimedia on their websites, only 59\% use figures and graphs. The number of companies that use their website for internet financial reporting is 154 out of 246 (63\%) and 57\% of the companies have the current annual report (2012) disclosed. A breakdown of the overall results is shown in table 10.

Table 9. Overall Internet Disclosure Statistics

\begin{tabular}{llllll}
\hline Disclosure Attribute & Yes & $\mathbf{\%}$ & $\mathbf{N o}$ & $\mathbf{\%}$ & Total \\
\hline Investor Relation & 114 & $46 \%$ & 132 & $54 \%$ & 246 \\
CG Report & 52 & $21 \%$ & 194 & $79 \%$ & 246 \\
Email Link & 245 & $100 \%$ & 1 & -- & 246 \\
Multimedia & 217 & $88 \%$ & 29 & $12 \%$ & 246 \\
Company Information & 243 & $99 \%$ & 3 & $1 \%$ & 246 \\
Products \& Services Information & 242 & $98 \%$ & 4 & $2 \%$ & 246 \\
Forward Looking Information & 126 & $51 \%$ & 120 & $49 \%$ & 246 \\
Figures \& Graphs & 145 & $59 \%$ & 101 & $41 \%$ & 246 \\
General Financial Information & 166 & $67 \%$ & 80 & $33 \%$ & 246 \\
IFR & 154 & $63 \%$ & 92 & $37 \%$ & 246 \\
Current Annual Report & 139 & $57 \%$ & 107 & $43 \%$ & 246 \\
\hline
\end{tabular}

Table 10. Internet Disclosure Statistics by Country

\begin{tabular}{lll|ll}
\hline Variable & KSA & & Oman & \\
\cline { 2 - 5 } & Frequency & $\mathbf{\% *}$ & Frequency & $\mathbf{\% * *}$ \\
\hline Investor Relation & 96 & $64 \%$ & 18 & $19 \%$ \\
CG Report & 44 & $29 \%$ & 8 & $8 \%$ \\
Email Link & 150 & $100 \%$ & 95 & $100 \%$ \\
Multimedia & 137 & $91 \%$ & 80 & $83 \%$ \\
Company Information & 150 & $100 \%$ & 93 & $97 \%$ \\
Products \& Services Information & 149 & $99 \%$ & 93 & $97 \%$ \\
Forward Looking Information & 81 & $54 \%$ & 45 & $47 \%$ \\
Figures \& Graphs & 124 & $83 \%$ & 21 & $22 \%$ \\
General Financial Information & 117 & $78 \%$ & 49 & $51 \%$ \\
IFR & 103 & $69 \%$ & 51 & $53 \%$ \\
Current Annual Report & 92 & $61 \%$ & 47 & $49 \%$ \\
\hline
\end{tabular}

* Based on a total number of 150 companies with websites in KSA

** Based on a total number of 96 companies with websites in Oman 


\subsection{Hypothesis Testing}

Mann-Whitney test is used to test the first hypothesis. For testing the remaining five hypotheses $\left(\mathrm{H}_{2}-\mathrm{H}_{6}\right)$, Logistic Regression is used to examine the determinants of IFR in the GCC countries.

Table 11 reveals that there are significant differences at $1 \%$ level between the corporate internet disclosure among the two GCC countries in terms of corporate governance report ( $\mathrm{z}$ $=-4.399)$, products and services information $(\mathrm{z}=-4.237)$, general financial information $(\mathrm{z}=$ -5.500), investor relations $(z=-7.612)$, the use of figures and graphs $(z=-10.094)$, internet financial reporting $(z=-3.616)$, the disclosure of current annual report $(z=-2.986)$, the multimedia content $(\mathrm{z}=-3.891)$ and Email link $(\mathrm{z}=-4.462)$ as shown in table 11. While significant at $5 \%$ level for forward looking information $(z=-2.114)$. These results support the first hypothesis that there is a significant difference in the characteristics of corporate internet disclosure among the two GCC countries.

Table 11. Mann-Whitney Test Results

\begin{tabular}{lllll}
\hline \multirow{2}{*}{ Variable } & \multicolumn{3}{c}{ Mean Rank } & \multicolumn{3}{c}{ Mann-Whitney } \\
\cline { 2 - 5 } & KSA & Oman & z-value & Sig. \\
\hline EWeb & 140.89 & 123.49 & $-3.993^{* *}$ & 0.000 \\
AWeb & 174.68 & 77.55 & $-12.157^{* *}$ & 0.000 \\
Investor Relation & 159.95 & 97.69 & $-7.612^{* *}$ & 0.000 \\
Figures \& Graphs & 168.79 & 85.72 & $-10.094^{* *}$ & 0.000 \\
Email Link & 141.76 & 122.31 & $-4.462^{* *}$ & 0.000 \\
Multimedia & 144.09 & 119.16 & $-3.891^{* *}$ & 0.000 \\
Format & 146.04 & 116.53 & $-3.616^{* *}$ & 0.000 \\
CG Report & 145.75 & 116.92 & $-4.399^{* *}$ & 0.000 \\
Company Information & 142.39 & 121.46 & $-4.506^{* *}$ & 0.000 \\
Products \& Services Information & 142.02 & 121.96 & $-4.237^{* *}$ & 0.000 \\
Forward Looking Information & 140.91 & 123.46 & $-2.114^{*}$ & 0.035 \\
General Financial Information & 152.21 & 108.17 & $-5.500^{* *}$ & 0.000 \\
IFR & 146.04 & 116.53 & $-3.616^{* *}$ & 0.000 \\
Current Annual Report & 143.97 & 119.32 & $-2.986^{* *}$ & 0.003 \\
IFRYrs & 144.31 & 118.86 & $-2.842^{* *}$ & 0.004 \\
\hline
\end{tabular}

* Sig. at 5\% level.

** Sig. at $1 \%$ level.

The following equation is used to test hypotheses two to six:

$$
\text { IFR }=\alpha+\beta_{1} R O A+\beta_{2} \text { AudTyp }+\beta_{3} \text { IndTyp }+\beta_{4} \operatorname{Lvg}+\beta_{5} \text { FrmSize }+\varepsilon
$$

Using Logistic regression to examine the determinants of IFR in the GCC countries (Tadawul, and MSM), as in the equations above. Where, Where, $\mathrm{Chi}^{2}=39.595$, Cox and snell $\mathrm{R}^{2}=$ 0.138 . The results in Table 12 show that the only factor that significantly impact internet 
financial reporting in the GCC countries is firm size, where Wald $=29.373$ ( $p$-value $=0.000$ ) at $1 \%$ level. All other variables show insignificant effect on internet financial reporting in the two countries. The results are consistent with the findings of previous studies (Ashbaugh et al., 1999; Craven and Marston, 1999; Pirchegger and Wagenhofer, 1999; Debreceny et al., 2002; Ettredge et al., 2002; Oyelere et al., 2003; Fisher et al., 2004; Chan and Wickramasinghe, 2006; Trabelsi, 2007; Ezat and El-Masry, 2008).

The results can be justified by the fact that to reduce these agency costs, larger firms disclose a large flow of corporate information (Jensen and Meckling, 1976). Also, large companies are more likely to use information technology than small ones to improve financial reporting to meet the greater demand for information (Xiao et al., 1996). The relative cost of disclosing information may also be lower than smaller ones (Oyelere et al., 2003). Furthermore, according to the political cost hypothesis it is argued that larger firms face more demands for information from analysts than smaller firms (McKinnon and Dalimunthe, 1993; Boubaker et al., 2012).

Table 12. Logistic Regression Results

\begin{tabular}{|c|c|c|c|c|}
\hline \multirow[b]{2}{*}{ Variables } & \multicolumn{4}{|c|}{ Dependent Variable (IFR) } \\
\hline & Coefficient & SE & Wald & $p$-value \\
\hline $\mathrm{ROA}$ & 0.167 & 1.204 & 0.019 & 0.890 \\
\hline AudTyp & -0.229 & 0.370 & 0.384 & 0.536 \\
\hline InTyp & -0.094 & 0.180 & 0.271 & 0.603 \\
\hline Lvg & -0.680 & 0.582 & 1.366 & 0.243 \\
\hline FrmSize & 0.457 & 0.084 & $29.373^{* *}$ & 0.000 \\
\hline Constant & -8.315 & 1.596 & $27.138 * *$ & 0.000 \\
\hline Cox and Snell R2 & \multicolumn{4}{|c|}{0.138} \\
\hline Chi-square & \multicolumn{4}{|c|}{$39.595(\mathrm{df}=5)$} \\
\hline$n$ & \multicolumn{4}{|l|}{266} \\
\hline
\end{tabular}

**Sig. at $1 \%$ level

\section{Summary and Conclusion}

This paper investigates and reports on the extent, nature and determinants of IFR practices among companies listed in Tadawul and MSM. As there is little empirical study on IFR practices in the Middle East region this paper is an important contribution to filling the gap the literature. The paper provides insights into IFR in the Middle East that will benefit all stakeholders with an interest in corporate reporting. Data has been collected and analysed on 266 companies listed on the stock markets in Saudi Arabia and Oman. While 246 of these companies maintain websites, only 154 provide internet financial reporting on their websites. The majority of these companies use the PDF format to publish financial information and some companies use the internet to provide additional financial information, in the form of financial highlights. This study reveals a good use of the internet for financial reporting purposes in Saudi Arabia and Oman. 
The results show that large firms tend to disclose more financial information in order to reduce information asymmetry and also reduce agency costs. Also, the more exposure large firms are subjected to leads to the firms being under higher pressure to disclose information. Large corporations seem to disclose information on the internet due to the fact they can benefit from the lower cost that results from these firms having the resources to do so. Additionally, the results are consistent with agency theory that large firms attempt to reduce the high agency costs associated with information asymmetry between market participants by disclosing a large flow of corporate information. Furthermore, according to the political cost hypothesis, large firms attract more financial analysts putting firms under higher pressure because they are more publicly visible.

The benefits to be derived from IFR in the modern era of globalisation and endemic market inter-linkages are likely to far outweigh the pecuniary costs. The current level of technological expertise and development in the Arabian Gulf is more than adequate for the creation, operation and maintenance of corporate websites for IFR purposes. However, perceptions about cost and technological expertise may be limiting the widespread implementation of IFR among companies in the Arabian Gulf. Nonetheless, apart from initial set-up costs, which are relatively minor, the ongoing long-term costs of operating and maintaining corporate websites for IFR purposes are minimal. However, the results show that large firms tend to disclose more financial information in order to reduce information asymmetry and also reduce agency costs. Also, the more exposure large firms are subjected to leads to the firms being under higher pressure to disclose information. Perhaps the "novelty" factor is the main factor responsible for the current low uptake of IFR among companies in Saudi Arabia and Oman. This is likely to be generalisable to other countries in the Arabian Gulf region, and possibly the broader Middle East. If that is the case, the region is likely to witness an upsurge in IFR over the next few years and regulators and other governmental agencies, as well as other stakeholder groups will need to be prepared for this imminent development. Nonetheless, there is little by way of regulatory guidance or pronouncement on IFR in Saudi Arabia and Oman and perhaps in most countries of the Middle East. This situation needs to be remedied in advance.

\section{References}

Abd El Salam, O.H. (1999). The introduction and application of international accounting standards to accounting disclosure regulations of a capital market in developing country: the case of Egypt, PhD thesis, Heriot-Watt University, Edinburgh.

Ahmed, K., \& Nicholls, D. (1994). The impact of non-financial company characteristics on mandatory disclosure compliance in developing countries: the case of Bangladesh. The International Journal of Accounting, 29, 62-77.

Allam, A., \& Lymer, A. (2002). Benchmarking Financial Reporting Online: The 2001 Review. Working Paper, University of Birmingham, Birmingham, UK.

Almilia, S., \& Surabaya, S. (2009). Determining factors of internet financial reporting in Indonesia. Accounting and Taxation, 1(1), 87-99. 
Aly, D., Simaon, J., \& Hussainey, K. (2009). Determinants of CIR: evidence from Egypt. Managerial Auditing Journal, 25(2),

182-202. http://dx.doi.org/10.1108/02686901011008972.

Ashbaugh, H., Johnstone, K., \& Warfield, T. (1999). Corporate reporting on the Internet. Accounting Horizons, 13(3), 241-257. http://dx.doi.org/10.2308/acch.1999.13.3.241.

Baker, C. R., \& Wallage, P. (2000). The Future of Financial Reporting in Europe: Its Role in Corporate Governance. The International Journal of Accounting, 35(2), 173-187. http://dx.doi.org/10.1016/S0020-7063(00)00044-3

Bollen, L., Hassink, H. and Bozic, G. (2006). Measuring and explaining the quality of internet investor relations activities: a multinational empirical analysis. International Journal of Accounting Information Systems, 273-98. http://dx.doi.org/10.1016/j.accinf.2006.04.005.

Bonson, E., \& Escobar, T. (2002). A survey on voluntary disclosure on the internet: empirical evidence from 300 European Union companies. The International Journal of Accounting Research, 2(1), 27-51.

Boritz, J., \& No, W. (2005). Security in XML-Based Financial Reporting Services on the Internet. Journal of Accounting and Public Policy, 24(1), 11-35. http://dx.doi.org/10.1016/j.jaccpubpol.2004.12.002.

Boubaker, S., Lakhal, F., \& Nekhili, M. (2012). The determinants of web-based corporate reporting in France. Managerial Auditing Journal, 27(2), 126-155. http://dx.doi.org/10.1108/02686901211189835.

Brennan, N., \& Hourigan, D. (1998). Corporate reporting on the internet by Irish companies. Accountancy Ireland, 30(6), 18-21.

Chan, W.K., \& Wickramasinghe, N. (2006). Using the Internet for Financial Disclosures: The Australian Experience. International Journal of Electronic Finance, 1(1), 118-150.

Craven, B., \& Marston, C. (1999). Financial reporting on the Internet by leading UK companies. The European Accounting Review, 8(2), 321-333. http://dx.doi.org/10.1080/096381899336069.

DeAngelo, L. E. (1981). Auditor size and audit quality. Journal of Accounting and Economics, 3(30), 183-199. http://dx.doi.org/10.1016/0165-4101(81)90002-1.

Debreceny, R., \& Rahman, A. (2005). Firm-specific determinants of continuous corporate disclosure. The International Journal of Accounting, 40, 249-78. http://dx.doi.org/10.1016/j.intacc.2005.06.002.

Debreceny, R., Gray, G., \& Rahman, A. (2002). The determinants of Internet financial reporting. Journal of Accounting and Public Policy, 21(4/5), 371-394. http://dx.doi.org/10.1016/S0278-4254(02)00067-4. 
Deller, D., Stubenrath, M., \& Weber, C. (1999). A Survey on the Use of the Internet for Investor Relations in the USA, the UK and Germany. The European Accounting Review, 8(2), 351-364. http://dx.doi.org/10.1080/096381899336087.

Ettredge, M., Richardson, V.,, \& Scholz, S. (2001). The Presentation of Financial Information at Corporate Websites. International Journal of Accounting Information Systems, 2, 149-168. http://dx.doi.org/10.1016/S1467-0895(00)00017-8.

Ettredge, M., Richardson, V.,, \& Scholz, S. (2002). Dissemination of information for investors at corporate Web sites'. Journal of Accounting and Public Policy, 21(4/5), 357-369. http://dx.doi.org/10.1016/S0278-4254(02)00066-2.

Ezzat, A.,, \& El-Masry, A. (2008). The impact of corporate governance on the timeliness of corporate internet reporting by Egyptian listed companies. Managerial Finance, 34(12), 848 - 867. http://dx.doi.org/10.1108/03074350810915815.

FASB (Financial Accounting Standard Board) (2000). Electronic Distribution of Business Reporting Information, Business Reporting Research Project, available at: http://accounting.rutgers.edu/raw/fasb/brrp1.pdf.

Fisher, R., Oyelere, P., \& Laswad, F. (2003). Corporate Reporting on the Internet: Audit Issues and Content Analysis of Practices. Paper presented at the 2003 Annual Conference of the British Accounting Association, Manchester, April 23-25.

Fisher, R., Oyelere, P., \& Laswad, F. (2004). Corporate Reporting on the Internet: Audit Issues and Content Analysis of Practices. Managerial Auditing Journal, 19(3), 412-139. http://dx.doi.org/10.1108/02686900410524418.

García-Borbolla, A., Larrán, M., \& López, R. (2005). Empirical evidence concerning SMEs' corporate websites: Explaining factors, strategies and reporting. The International Journal of Digital Accounting Research, 5, 171-202.

Gowthorpe, C. (2004). Asymmetrical Dialogue? Corporate Financial Reporting Via the Internet. Corporate Communication: An International Journal, 9(4), 283-293. http://dx.doi.org/10.1108/13563280410564020.

Gowthorpe, C., \& Amat, O. (1999). External Reporting of Accounting and Financial Information via the Internet in Spain. The European Accounting Review, 8(2), 365-371. http://dx.doi.org/10.1080/096381899336096.

Gowthorpe, C., \& Flynn, G. (2001). Smaller Listed Companies' Financial Reporting on the Internet 2000/2001, Institute of Chartered Accountants in England and Wales, London, UK.

Green, G., \& Spaul, B. (1997). Digital Accountability. Accountancy, International Edition, May, 49-50.

Hail, L. (2002). The impact of voluntary corporate disclosures on the ex ante cost of capital for Swiss firms. European Accounting Review, 11(11), 741-73. http://dx.doi.org/10.1080/0963818022000001109. 
Haniffa, R., \& Cooke, T. (2005). The impact of culture and governance on corporate social reporting. Journal of Accounting and Public Policy, 24(5), 391-430. http://dx.doi.org/10.1016/j.jaccpubpol.2005.06.001.

Healy, P., \& Palepu, K. (2001). Information asymmetry, corporate disclosure, and the capital markets: a review of the empirical disclosure literature. Journal of Accounting and Economics, 31, 405-40. http://dx.doi.org/10.1016/S0165-4101(01)00018-0.

Hedlin, P. (1999). The Internet as a Vehicle for Investor Relations: the Swedish Case. The European Accounting Review, 8(2), 373-381. http://dx.doi.org/10.1080/096381899336104.

Hodge, F. (2001). Hyper linking Unaudited Information to Audited Financial Statements: Effects on Investor Judgements. The Accounting Review, 76(4), 675-691. http://dx.doi.org/10.2308/accr.2001.76.4.675.

Hossain, M., Perera, M., \& Rahman, A. (1995). Voluntary disclosure in the annual reports of New Zealand companies. Journal of International Financial Management, \& Accounting, 6(1), 69-87. http://dx.doi.org/10.1111/j.1467-646X.1995.tb00050.x.

Ismail, T. (2002). An empirical investigation of factors influencing voluntary disclosure of financial information on the internet in the GCC countries. available at: http://ssrn.com/abstract=420700.

Ismail, T., \& Sobhy, N. (2009). Determinants of auditors' perceptions of the work needed in the audit of internet-based financial reports in Egypt. Journal of Applied Accounting Research, 10(2), 132-150. http://dx.doi.org/10.1108/09675420910984691.

Jensen, M., \& Meckling, W. (1976). Theory of the firm: Managerial behaviour, agency costs and ownership structure. Journal of Financial Economics, 3(4), 305-360. http://dx.doi.org/10.1016/0304-405X(76)90026-X.

Jones, M., \& Xiao, J. (2004). Financial Reporting on the Internet by 2010: A Consensus View. Accounting Forum, 24, 237-263. http://dx.doi.org/10.1016/j.accfor.2004.07.002.

Khadaroo, I. (2005). Corporate Reporting on the Internet: Some Implications for the Auditing Profession. Managerial Auditing Journal, 20(6), 578-591. http://dx.doi.org/10.1108/02686900510606074.

Larran, M., \& Giner, B. (2002). The use of the internet for corporate reporting by Spanish companies. The International Journal of Digital Accounting Research, 2(3), 53-82.

Laswad, F., Fisher, R. and Oyelere, P. (2005). Determinants of voluntary Internet financial reporting by Local Government Authorities. Journal of Accounting and Public Policy, 24, 101-121. http://dx.doi.org/10.1016/j.jaccpubpol.2004.12.006

Laswad, F., Oyelere, P., \& Fisher, R. (2000). Internet Financial Reporting, Opportunities and Challenges. African Finance Journal, 2(2), 40-46. 
Leftwich, R. (1981). Evidence of the impact of mandatory changes in accounting principles on corporate loan agreements. Journal of Accounting and Economics. (March), 3-36. http://dx.doi.org/10.1016/S0165-4101(81)80001-8.

Louwers, T., Pasewark, W., \& Typpo, E. (1996). Silicon Valley meets Norwalk. Journal of Accountancy, 186, 20-24.

Lymer, A. (1999). The Internet and the Future of Corporate Reporting in Europe. The European Accounting Review, 8(2), 289-301. http://dx.doi.org/10.1080/096381899336041.

Lymer, A.,, \& Debreceny, R. (2003). The auditor and corporate reporting on the internet: Challenges and institutional responses. International Journal of Auditing, 7(2), 103-120. http://dx.doi.org/10.1111/1099-1123.00063.

Lymer, A., Debreceny, R., Gray, G., \& Rahman, A. (1999). Business Reporting on the Internet, International Accounting Standards Committee, London, November.

Malone, D., Fries, C., \& T. Jones. (1993). An empirical investigation of the extent of corporate financial disclosure in the oil and gas industry. Journal of Accounting, Auditing and Finance, 8, 249-273.

Marston, C. (2003). Financial Reporting on the Internet by Leading Japanese Companies. Corporate Communication: An International Journal, 8(1), 23-34. http://dx.doi.org/10.1108/13563280310458894.

Marston, C., \& Polei, A. (2004). Corporate Reporting on the Internet by German Companies. International Journal of Accounting Information Systems, 5, 285-311. http://dx.doi.org/10.1016/j.accinf.2004.02.009.

McCafferty, J. (1995). Investor Relations: How Much to Reveal Online. CFO, December, 12-13.

McKinnon, J., \& Dalimunthe, L. (1993). Voluntary disclosure of segment information by Australian diversified companies. Accounting, \& Finance, 33(1), 33-50. http://dx.doi.org/10.1111/j.1467-629X.1993.tb00192.x.

Meek, G., Roberts, C., \& Gray, S. (1995). Factors Influencing Voluntary Annual Report Disclosure by U.S, U.K and Continental European Multinational Corporations. Journal of International Business $\quad$ Studies, 26(3), 555-572. http://dx.doi.org/10.1057/palgrave.jibs.8490186.

Mitchell, J., Chia, C., \& Loh, A. (1995). Voluntary disclosure of segment information: Further Australian evidence. Accounting, \& Finance, 35(2), 1-16. http://dx.doi.org/10.1111/j.1467-629X.1995.tb00283.x.

Mohamed, E. (2010). Internet financial reporting (IFR) in the GCC: Extent and practices. International Journal of Accounting and Finance, 2(1), 113-129. http://dx.doi.org/10.1504/IJAF.2010.031914. 
Mohamed, E., Oyelere, P.,, \& Al-Busaidi, M. (2009). A survey of internet financial reporting in Oman. International Journal of Emerging Markets, 4(1), 56-71.

Momany, M., \& Al-Shorman, S. (2006). Web-based voluntary financial reporting of Jordanian companies. International Review of Business Research Papers, 2, 127-39.

Oyelere, P., Laswad, F., \& Fisher, R. (2003). Determinants of Internet Financial Reporting by New Zealand Companies. Journal of International Financial Management and Accounting, 14(1), 26-63. http://dx.doi.org/10.1111/1467-646X.00089.

Pirchegger, B., \& Wagenhofer, A. (1999). Financial Information on the Internet: A Survey of the Homepages of Austrian Companies. The European Accounting Review, 8(2), 383-395. http://dx.doi.org/10.1080/096381899336113.

Raffournier, B. (1995). The determinants of voluntary financial disclosure by Swiss listed companies. European Accounting Review, 4(2), 261-80. http://dx.doi.org/10.1080/09638189500000016.

Ravlic, T. (2000). Wild Wild Web. Australian CPA, August, 26-30.

Salawu, R.O. (2009). Financial reporting on the internet by quoted companies in Nigeria. Proceedings of the 10th Annual Conference of Repositioning African Business and Development for the 21st Century. Retrieved on 15th of March 2013 from http://www.iaabd.org/2009_iaabd_proceedings/track1a.pdf.

SEC (Securities and Exchange Commission) (2002) Final Rule: Acceleration of Periodic Report Filing Dates and Disclosure Concerning Website Access to Reports, Securities and Exchange Commission, available at: www.sec.gov

SEC (Securities and Exchange Commission) (2003a) Final Rule: Disclosure Required by Sections 406 and 407 of the Serbanes-Oxley Act of 2002, Securities and Exchange Commission, available at: www.sec.gov

SEC (Securities and Exchange Commission) (2003b) Final Rule: Mandated Electronic Filing and Website Posting for Form 3,4 and 5, Securities and Exchange Commission, available at: www.sec.gov

Singhvi, S., \& Desai, H. (1971). An empirical analysis of the quality of corporate financial disclosure. Accounting Review, 46(1), 129-38.

Smith, B., \& Peppard, D. (2005). Internet Financial Reporting: Benchmarking Irish PLCs against Best Practice. Accountancy Ireland, 37(6), 22-24

Sriram, R.S., \& Laksmana, I. (2006). Corporate website reports: some evidence on relevance and usefulness. Information Resources Management Journal, 19, 1-17. http://dx.doi.org/10.4018/irmj.2006070101

Trabelsi, S., \& Labelle, R. (2006). Evidence that corporate websites is a part of the firm's overall disclosure package. working paper, Brock University, St Catherines, available at: http://accounting.uwaterloo.ca/seminars/old_papers/ 


\section{Macrothink}

Asian Journal of Finance \& Accounting ISSN 1946-052X 2014, Vol. 6, No. 1

Trites, G. (1999). The Impact of Technology on Financial and Business Reporting. Canadian Institute of Chartered Accountants.

Trites, G., \& Sheehy, D. (1997). Electronic Disclosure Making a Hit on the Net. CA Magazine, March, 10-11.

Wagenhofer, A. (2003). Economic Consequences of Internet Financial Reporting. Schmalenbach Business Review, 55, October, 262-279.

Wallace, R., Naser, K., \& Mora, A. (1994). The relationship between the comprehensiveness of corporate annual reports and firm characteristics in Spain. Accounting, \& Business Research, 25(97), 41-53. http://dx.doi.org/10.1080/00014788.1994.9729927.

Wallman, S. (1997). The Future of Accounting and Financial Reporting, Part 5: Access Accounting. Accounting Horizon, 11(2), 103-116.

Wickramasinghe, N. (2006). Knowledge Creation: A Meta-Framework. International Journal of Innovation and Learning, 3(5), 558-573.

Wickramasinghe, N., \& Lichtenstein, S. (2006). Supporting Knowledge Creation With E-mail. International Journal of Innovation and Learning, 3(4), 416-426.

Xiao, J., Dyson, R., \& Powell, P. (1996). The impact of information technology on corporate financial reporting: a contingency perspective. British Accounting Review, 28(3), 203-27. http://dx.doi.org/10.1006/bare.1996.0015.

Xiao, J., Yang, H., \& Chow, C. (2004). The Determinants and Characteristics of Voluntary Internet-Based Disclosures by Listed Chinese Companies. Journal of Accounting and Public Policy, 23(3), 191-225. http://dx.doi.org/10.1016/j.jaccpubpol.2004.04.002. 